\title{
Bridging the Gaps between Teacher Educators and Student Teachers' Perceptions about the Attributes of Effective Teacher Educators
}

\section{Sayit Abdul Karim}

Universitas Teknologi Yogyakarta, Jl. Siliwangi Jl. Ring Road Utara, Jombor Lor, Sendangadi, Kec. Mlati, Kabupaten Sleman, Daerah Istimewa Yogyakarta 55285, Indonesia

Email: sayit.a.k@uty.ac.id

DOI: 10.18326/rgt.v14i1.1-24

Submission Track:

Received: 07-01-2021

Final Revision: 28-04-2021

Available Online: 01-05-2021

Copyright @ 2021 Author

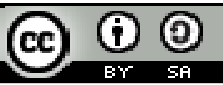

This work is licensed under a Creative Commons Attribution-ShareAlike 4.0 International License.

\begin{abstract}
The present study attempts to investigate effective EFL teacher educators from the perspectives of student teachers and teacher educators. A survey design was employed to examine student teachers' and teacher educators' perceptions of the attributes of effective EFL teacher educators. Furthermore, an adapted questionnaire was administered online to 408 participants (334 student teachers, and 74 teacher educators) to obtain data about effective EFL teacher educators using four categories of attributes of effective teacher educators, namely subject matter knowledge (SMK), pedagogical knowledge (PK), organization and communication skills (OCS), and socio-affective skills (SAS). Descriptive statistical analyses were conducted for the measurement of central tendency. The findings revealed the student teachers and teacher educators have different perceptions of how they perceived effective EFL teacher educators. There was a significant statistical difference between student teachers' and teacher educators' perceptions of the three categories of attributes, namely SMK, PK, and OCS. Meanwhile, there was no significant statistical difference between student teachers' and teacher educators' perceptions of SAS. The results of the present study may serve several pedagogical implications in the program of teacher education context.
\end{abstract}

Keywords: EFL student teachers, teacher Educators, effective teacher, perceptions 


\section{INTRODUCTION}

The teacher educators' roles and responsibilities in tertiary education are very important due to their position as a role model for student teachers (Goodwin \& Kosnik, 2013:334). In the university context, teacher educator is one of the key components in obtaining effective learning and teaching (Al-Issa, 2017). Effective teaching and learning can be achieved if teacher educators understand the attributes of effective teachers. Besides, teacher educators should know what student teachers expect from them to facilitate their learning needs and achieve the goals of foreign language teaching (Said, 2017).

According to Alimorad and Tajgozari (2016:1), acknowledging the perceptions of the effectiveness of language teaching practices is an important effort because more satisfactory learning outcomes will be achieved. To keep obtaining effective learning and teaching atmosphere, we need to ignite a large number of effective EFL teacher educators who provide a good atmosphere (Arikan, Taser, \& Suzer, 2008:43). In university settings, Chen, (2012: 213) found out that an EFL teacher educator is one of the main elements that may influence students' achievement.

The discrepancies between EFL teacher educators' and student teachers' perceptions of effective EFL teacher educators can adversely affect student teachers' ultimate achievement, learning attitudes, motivations, and learning outcomes (Zamani \& Ahangari, 2016:69). Meanwhile, Alimorad and Tajgojari (2016:1) found out that the mismatches of their perceptions can cause problems in the teaching and learning process, and may cause students' dissatisfaction with their learning outcome. Without such comprehensive knowledge, teachers will harm the students' long-term development and professional learning (Yuan \& Hu, 2018:2).

The government of Indonesian has very much concerned about the teachers' and lecturers' quality and competence standard by establishing what so-called Badan Standar Nasional Pendidikan (BSNP) or the Board for the National Standard of Education. It is aimed at improving the quality and helping teachers require competencies, Apart from BSNP, the Indonesian government also concerns with the development and improvement of education quality from the secondary to the university levels by establishing the National 
Qualification Framework or known as Kerangka Kualifikasi Nasional Indonesia (KKNI). As a whole, one of the KKNI implementation strategies is to be a guideline and reference for the development and improvement of education quality from the secondary to the university levels (Anugerahwati, 2009).

Further research is needed to find out the perceptions of effective EFL teacher educators from both perspectives of student teachers and EFL teacher educators using the concept of characteristics of effective EFL teachers which are suggested by Park \& Lee (2006) and Wichadee (2010). The reason why I use their concept of characteristics of effective EFL teacher educators because their concepts meet the nature of the topic under investigation and cover the ideal characteristics of effective EFL teacher educators as required by the BSNP concerning the teachers' and lecturers' quality and competence standard. Besides, it is in line with the UUGD, concerning teachers' competences: pedagogical knowledge (PK), organization and communication skills (OCS), socio-affective skills (SAS), and English proficiency (EP).

To this end, it is significant to investigate how EFL teacher educators and student teachers perceive the characteristics of effective EFL teacher educators. Without such comprehensive knowledge, teacher educators bring a negative impact to the development of their students (Yuan \& Hu: 2018:2). Therefore, the present study attempts to answer the research questions: What are the differences between student teachers' and EFL teacher educators' perceptions about the characteristics of effective teacher educators in terms of subject matter knowledge (SMK), pedagogical knowledge (PK), organization and communication skills (OCS), and socio-affective skills (SAS)?

\section{LITERATURE REVIEW}

It is natural for the EFL teacher educators to possess certain attributes of an effective teacher educator (Dincer, Goksu, Takkac, \& Yazici, 2013:2). Literature review shows that there are various perspectives of effective EFL teacher educators' attributes purposed by several of experts. For instance, Clark and Walsh (2002) found out the general attributes that describe effective teacher educators' quality: have strong discipline content knowledge, pedagogical skills, personal knowledge; a strong relationship with the students, and possess great knowledge of what they are teaching. 
Another perspective of the attributes is proposed by Cheung (2006:435436) who states that a highly effective teacher educator is someone who does as follows: allocates more time to preparation and delivery, responds to students' needs, tolerant to students' mistakes, provide their time with students who have problems, and tries to assist their students' learning. Meanwhile, Thompson, Greer, and Greer (2004) propose some common attributes, namely: show a positive outlook, humor, care, fairness, creativity, use a personal touch, maintain high expectations, compassion, being prepared, being forgiving, and have a sense of belonging for students.

In connection with the concept of characteristics of effective EFL teacher educators, Park and Lee (2006) point out that there are three attribute categories, namely subject matter knowledge or known as EP, PK, and SAS which demonstrate the dimensions of knowledge. The attributes of effective teacher educators which are proposed by Park and Lee (2006) are in line with the Indonesian norm as stated in the BSNP through the National Ministry of Education Regulation (Peraturan Menteri Pendidikan Nasional) No.16 the Year 2007. It formulates the standards to be used to evaluate teachers' academic qualifications and competencies.

Meanwhile, Wichadee (2010) extends Park's and Lee's (2006) concept of effective EFL teacher educators based on her literature review by adding one attribute category namely organization and communication skills. It is the knowledge of EFL teacher educators to prepare the lesson well, to make the course interesting, to use easy language to assist students in understanding learning materials, maintain a good classroom atmosphere, and provide chances to use English through meaningful activities and tasks.

Several studies have been conducted on EFL student teachers' perceptions of effective EFL teacher educators. For instance, Arikan, Taser, and Suzer (2008) carried out a study to explored Turkish EFL learners' perceptions of effective EFL teacher educators. The findings reveal that an effective teacher is an enthusiastic, friendly, creative, and humorous person.

Wichadee (2010) conducted a study to investigate the characteristics of effective English language teachers from different groups of students; using four categories of attributes namely SMK, PK, OCS, and SAS. The results showed 
that the students placed the OCS as important on overall attributes at a high level with the highest ranking. However, in Wichadee's study (2010), an effective English language teacher was seen from student-centered perception only, therefore she suggests for future researchers to include both students and teachers.

Meanwhile, Kourieos and Evripidou (2013) carried out a study on students' perceptions of effective EFL teacher educators in tertiary settings under three separate thematic areas; they are, SMK, personal and interpersonal characteristics, and approach to language teaching. The findings revealed that an effective EFL teacher educator is someone who considers students' differences and abilities. interests, and language anxiety.

In the Indonesian context, a study into students' perceptions of effective EFL teacher educators was conducted by Mudra (2018). He researched effective lecturers' attributes as perceived by EFL learners in a public institution in Kerinci. The study is aimed at uncovering the attributes of effective English lecturers and to examine the difference between females' and males' perceptions of effective EFL lecturers. The findings revealed that males and females EFL learners have no significant different perceptions.

Apart from the study of effective EFL teacher educators from the students' perspective, other studies investigated the effective EFL teachers from the perspective of EFL teachers, for instance, Bell (2005), who conducted a study on behaviors and attitudes of effective EFL teacher educators. The study was aimed at finding out the perceptions of non-English teachers regarding the qualities of effective second language acquisition (SLA) teachers. The results showed that the standard for language learning and small group work was a strong majority agreement.

Another study was conducted by Khojastehmehr and Takrimi (2009). They conducted a study to find out what EFL teacher educators' view as necessary effective EFL teacher educators' attributes and to figure out EFL teacher educators' effectiveness factors. The findings showed that EFL teacher educators tend to show a multidimensional construct into four factors: skills of communication, personal characteristics, instructional strategies, and knowledge. The results indicate that instructional strategies were viewed as more critical for EFL teacher educators' effectiveness than other attributes. 
Studies regarding effective EFL teacher educators from both EFL teachers' and students' points of view were conducted by several researchers, for instance, Park and Lee (2006) carried out a study to find out the characteristics of effective English teachers utilizing three attribute categories namely SMK, PK, and SAS. The findings reveal that teachers perceived significantly different characteristics of EFL teachers than the students in all three categories. Moreover, teachers placed English proficiency as the highest important characteristics, while students placed PK as the highest.

Afshar and Doosti (2014) examined the attributes of effective Iranian EFL teachers from the perspectives of students and teachers. The findings showed that there was no significant difference in both EFL teachers' and students' perceptions of effective EFL teachers. They recommended that the future researcher replicate their study by including classroom observation, semistructured interview, and survey questionnaire to explore more about their perceptions

There have been numerous studies into attributes of the effective teacher from the perspectives of student teachers and teacher educators. There were different perceptions of teacher educators and student teachers on the attributes. Despite the plethora of studies about effective teacher educators, a quantitative study related to student teachers' and teacher educators' perception regarding the effective EFL teacher educators at the university level are still limited in numbers. Thus, the present study is conducted to fill the gaps in the methodological and variables that were not addressed by the aforementioned previous research. Besides, it is important to shed light on the issue of effective teacher educators in the Indonesian context, especially at the tertiary level.

\section{RESEARCH METHOD}

A survey design was applied to find out the perceptions of student teachers and teacher educators on effective EFL teacher educators using google form. For the present study, I adapted the research instrument which was developed by Park and Lee (2006), and Wichadee (2010). These concepts cover four attributes of effective EFL teachers including SMK, PK, OCS, and SAS. This 
research was conducted at the English Education Study Program (Program Studi Pendidikan Bahasa Inggris-PB-Ing), both state and private universities in Indonesia which are categorized into $A$ and $B$ accreditation levels.

The convenience sampling technique was applied to select the participants who meet the criteria of the present study. There were 408 participants in total from different universities within Indonesia who participated in the present study (334 ST and $74 \mathrm{TE}$ ). The accessible population was those available in the process of data gathering throughout Indonesia, such as in, East Java, Central Java, West Java, Bali, West Nusa Tenggara, and East Nusa Tenggara. A four-point Likert type scale is applied to gather the ordinal data from the participants' responses that were obtained through an online questionnaire.

\section{FINDINGS AND DISCUSSION}

\section{The Student Teachers' and Teacher Educators' Perceptions of the Subject-matter Knowledge}

The details of the differences between student teachers' and teacher educators' perceptions of the SMK can be seen in Table 1. Table 1 shows the teacher educators' mean score on the first indicator of subject matter knowledge is 3.73 which is higher than student teachers' perceptions on the same indicator which is 3.47. It means that teacher educators have higher perceptions pertaining that effective teacher educators should master the four language skills. Regarding indicator 2, teacher educators also have a higher means score (3.46) than student-teacher (3.24). It means that the student teachers have lower perceptions regarding that effective teacher educators should master the language components, e.g. vocabulary and pronunciation and grammar. Moreover, in indicator 3 , teacher educators have a higher mean score (3.84) than student teachers (3.53). It means that teacher educators have higher perceptions that effective teacher educators should have the cultural awareness of the target language. 


\section{S. A. Karim}

\section{Table 1}

The Differences between Student Teachers' and Teacher Educators' Perceptions of the Subject- Matter Knowledge

\begin{tabular}{|c|c|c|c|c|c|}
\hline \multirow[b]{2}{*}{ No } & \multirow[b]{2}{*}{ Statements } & \multicolumn{2}{|c|}{ Student Teacher } & \multicolumn{2}{|c|}{ Teacher Educator } \\
\hline & & Mean & $\begin{array}{l}\text { Mean Per } \\
\text { Indicator }\end{array}$ & Mean & $\begin{array}{l}\text { Mean Per } \\
\text { Indicator }\end{array}$ \\
\hline \multicolumn{6}{|c|}{$\begin{array}{l}\text { 1.1. Teacher educators master } \\
\text { the four language skills: }\end{array}$} \\
\hline 3 & $\begin{array}{l}\text { Be able to read English } \\
\text { well }\end{array}$ & 3.55 & & 3.76 & \\
\hline 5 & $\begin{array}{l}\text { Be able to write } \\
\text { English well }\end{array}$ & 3.39 & 3.47 & 3.71 & 3.73 \\
\hline 9 & $\begin{array}{l}\text { Be able to speak } \\
\text { English well }\end{array}$ & 3.48 & & 3.73 & \\
\hline \multicolumn{6}{|c|}{$\begin{array}{l}\text { 1.2. Teacher educators master } \\
\text { the language components (e.g. } \\
\text { Vocabulary, Pronunciation, } \\
\text { and Grammar: }\end{array}$} \\
\hline 4 & $\begin{array}{l}\text { Have a high level of } \\
\text { proficiency with } \\
\text { English vocabulary }\end{array}$ & 3.16 & 3.29 & 3.27 & 3.46 \\
\hline 7 & $\begin{array}{l}\text { Have good knowledge } \\
\text { of English grammar }\end{array}$ & 3.24 & & 3.57 & \\
\hline 10 & $\begin{array}{l}\text { Be able to pronounce } \\
\text { English words } \\
\text { correctly }\end{array}$ & 3.45 & & 3.55 & \\
\hline \multicolumn{6}{|c|}{$\begin{array}{l}\text { 1.3. Teacher educators have } \\
\text { the cultural awareness to } \\
\text { target language: }\end{array}$} \\
\hline 1 & $\begin{array}{l}\text { Have cultural } \\
\text { awareness of target } \\
\text { language }\end{array}$ & 3.53 & 3.53 & 3.84 & 3.84 \\
\hline
\end{tabular}

\section{The Student Teachers' and Teacher Educators' Perceptions of the Pedagogical Knowledge}

The details of the differences between student teachers' and teacher educators' perceptions of PK can be seen in Table 2. Table 2 shows the teacher educators' mean score (3.46) on the first indicator of pedagogical knowledge is higher than student teachers' perceptions on the same indicator (3.21). It means that teacher educators have higher perceptions regarding that effective teacher educators should master the instructional process. Concerning 
indicator 2, teacher educators also have a higher means score (3.56) than student-teacher (3.43). It means that the teacher educators have higher perceptions regarding that effective teacher educators should possess the classroom management (e.g. interactive learning styles). Furthermore, in indicator 3, teacher educators have a higher mean score (3.45) than student teachers (3.39). It means that teacher educators have higher perceptions that effective teacher educators must be able to use audio-visual aids when teaching. Although student teachers' and teacher educators 'perceptions are different in the three indicators of pedagogical knowledge, they agree that effective EFL teacher educators should possess classroom management as the first rank of effective EFL teacher educators. However, student teachers nominated the ability to use audio-visual aids when teaching is in the second, and master the instructional process is in the third rank. Meanwhile, teacher educators put master the instructional process in the second and have the ability to use audiovisual aids when teaching is in the third rank of effective EFL teacher educators.

\section{Table 2}

The Differences between Student Teachers' and Teacher Educators' Perceptions on the Pedagogical Knowledge

\begin{tabular}{|c|c|c|c|c|c|}
\hline \multirow{2}{*}{ No } & \multirow{2}{*}{ Statements } & \multicolumn{2}{|c|}{ Student Teacher } & \multicolumn{2}{|c|}{ Teacher Educator } \\
\hline & & Mean & $\begin{array}{l}\text { Mean Per } \\
\text { Indicator }\end{array}$ & Mean & $\begin{array}{l}\text { Mean Per } \\
\text { Indicator }\end{array}$ \\
\hline \multicolumn{6}{|c|}{$\begin{array}{l}\text { 2.1. Teacher educators master the } \\
\text { instructional process (e.g. planning, } \\
\text { teaching, and assessing) }\end{array}$} \\
\hline 14 & $\begin{array}{l}\text { Teach English tailored to students' } \\
\text { English proficiency levels }\end{array}$ & 3.17 & \multirow[t]{3}{*}{3.21} & 3.47 & \multirow[t]{3}{*}{3.46} \\
\hline 15 & $\begin{array}{l}\text { Teach English by using English as } \\
\text { a medium of instruction }\end{array}$ & 3.19 & & 3.42 & \\
\hline 16 & $\begin{array}{l}\text { Assess what students have } \\
\text { learned rationally }\end{array}$ & 3.25 & & 3.47 & \\
\hline \multicolumn{6}{|c|}{$\begin{array}{l}\text { 2.2. Teacher educators possess classroom } \\
\text { management }\end{array}$} \\
\hline 17 & $\begin{array}{l}\text { Teach English incorporating } \\
\text { students' various learning styles } \\
\text { (e.g. interactive learning style) }\end{array}$ & 3.34 & \multirow{2}{*}{3.43} & 3.47 & \multirow{2}{*}{3.56} \\
\hline 19 & $\begin{array}{l}\text { Provide interesting activities for } \\
\text { students in learning English }\end{array}$ & 3.53 & & 3.65 & \\
\hline
\end{tabular}


2.3. Teacher educators have the ability to use ICT in teaching

20 Be able to use audio-visual aids when teaching

\section{The Student Teachers' and Teacher Educators' Perceptions of the Organization and Communication Skills}

The details of the differences between student teachers' and teacher educators' perceptions of OCS can be seen in Table 3.

\section{Table 3}

The Differences between Student Teachers' and Teacher Educators' Perceptions of the Organization and Communication Skills

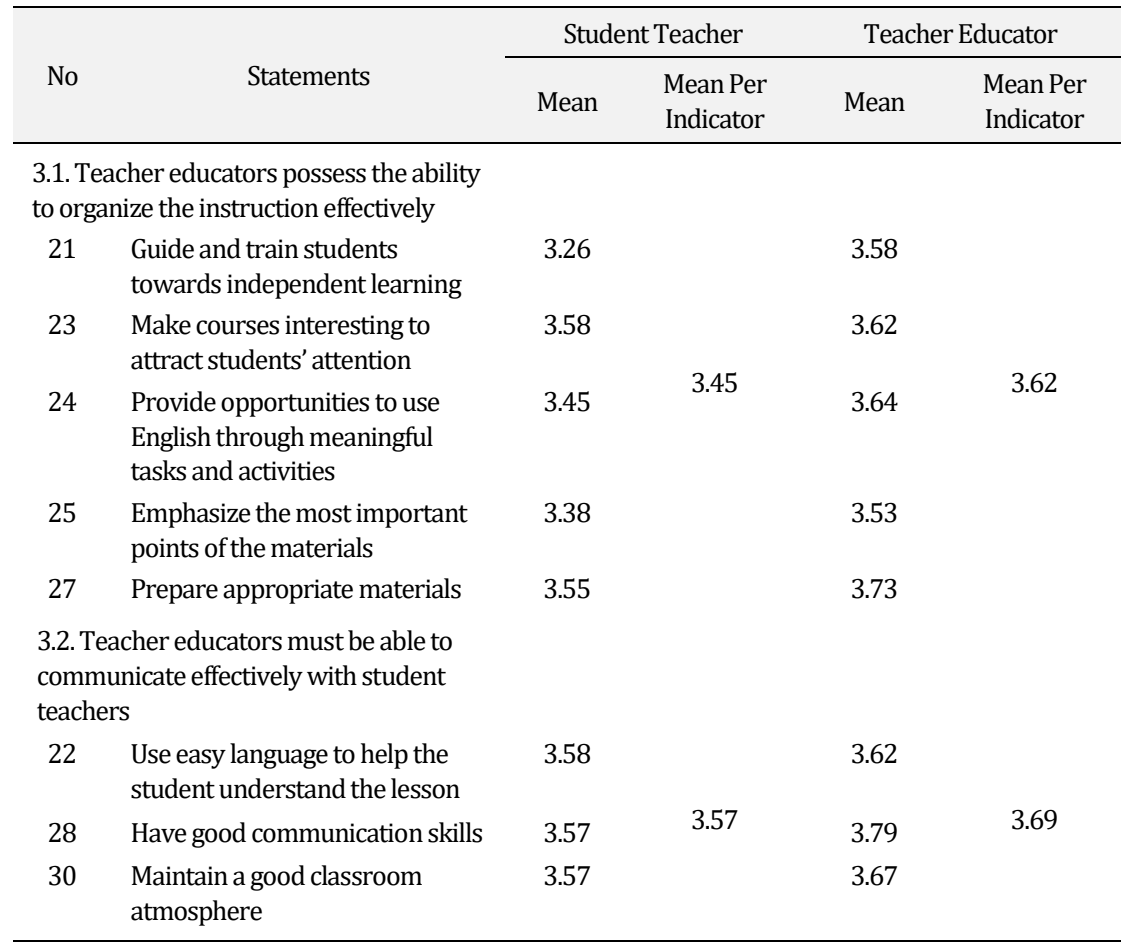

Table 3 shows the mean score of teacher educators in the first indicator of organization and communication skill is 3.62 which is higher than student teachers' perceptions on the same indicator which is 3.45 . It means that teacher 
educators have higher perceptions pertaining that effective teacher educators should possess the ability to organize the instruction effectively. Meanwhile, in indicator 2, teacher educators also have a higher means score (3.69) than student-teacher (3.57). It means that the teacher educators have higher perceptions regarding that effective teacher educators should be able to communicate effectively with student teachers.

\section{The Student Teachers' and Teacher Educators' Perceptions of Socio- Affective Skills}

The differences between student teachers' and teacher educators' perceptions of OCS can be seen in Table 4.

\section{Table 4}

The Differences between Student Teachers' and Teacher Educators' Perceptions of the Socio-affective Skills

\begin{tabular}{|c|c|c|c|c|c|}
\hline \multirow[b]{2}{*}{ No } & \multirow[b]{2}{*}{ Statements } & \multicolumn{2}{|c|}{ Student Teacher } & \multicolumn{2}{|c|}{ Teacher Educator } \\
\hline & & Mean & $\begin{array}{l}\text { Mean Per } \\
\text { Indicator }\end{array}$ & Mean & $\begin{array}{l}\text { Mean Per } \\
\text { Indicator }\end{array}$ \\
\hline \multicolumn{2}{|c|}{$\begin{array}{l}\text { 4.1. Teacher educators must be able } \\
\text { to perform a good attitude in } \\
\text { interacting with student teachers }\end{array}$} & & \multirow[t]{3}{*}{3.49} & & \multirow[t]{3}{*}{3.45} \\
\hline 35 & Be friendly to students & 3.64 & & 3.61 & \\
\hline 36 & Have a good sense of humor & 3.34 & & 3.29 & \\
\hline \multicolumn{2}{|c|}{$\begin{array}{l}\text { 4.2. Teacher educators must be able } \\
\text { to fully motivate, encourage, and } \\
\text { reduce students' anxiety }\end{array}$} & & \multirow[b]{2}{*}{3.49} & & \multirow[b]{2}{*}{3.34} \\
\hline 39 & $\begin{array}{l}\text { Have an interest in students } \\
\text { (e.g. remembering students' } \\
\text { names) and students' English } \\
\text { learning }\end{array}$ & 3.49 & & 3.34 & \\
\hline
\end{tabular}

Table 4 shows the teacher educators' mean score on the first indicator of socio-affective skills is 3.45 which is lower than student teachers' perceptions on the same indicator which is 3.49. It means that student teachers have higher perceptions pertain that effective teacher educators must be able to perform a good attitude in interacting with student teachers. Meanwhile, in indicator 2, student-teacher also has a higher means score (3.49) than teacher educators 
(3.34). It means that student teachers also have higher perceptions that effective teacher educators must be able to fully communicate, encourage, and reduce anxiety.

\section{The Student Teachers' and Teacher Educators' Perceptions of the Whole Attributes}

The details of the differences between student teachers' and teacher educators' perceptions of the whole attributes can be seen in Table 5.

\section{Table 5}

The Differences between Student Teachers' and Teacher Educators' Perceptions of the Whole Attributes

\begin{tabular}{|c|c|c|c|c|c|c|}
\hline \multirow[b]{2}{*}{ No. } & \multirow[b]{2}{*}{ Statements } & \multicolumn{2}{|c|}{ Student Teacher } & \multicolumn{2}{|c|}{ Teacher Educator } & \multirow[b]{2}{*}{$t$} \\
\hline & & $\begin{array}{l}\text { Mean Per } \\
\text { Indicator }\end{array}$ & Avrg & $\begin{array}{l}\text { Mean Per } \\
\text { Indicator }\end{array}$ & Avrg & \\
\hline \multirow[t]{4}{*}{1.} & Subject Matter Knowledge & & & & & \\
\hline & $\begin{array}{l}\text { 1.1. Teacher educators } \\
\text { master the four } \\
\text { language skills: }\end{array}$ & 3.47 & & 3.73 & & \\
\hline & $\begin{array}{l}\text { 1.2. Teacher educators } \\
\text { master the language } \\
\text { components (e.g. } \\
\text { Vocabulary, } \\
\text { Pronunciation, and } \\
\text { Grammar: }\end{array}$ & 3.29 & 3.39 & 3.46 & 3.63 & $\begin{array}{c}-2.948 \\
p=0.003\end{array}$ \\
\hline & $\begin{array}{l}\text { 1.3. Teacher educators } \\
\text { have the cultural } \\
\text { awareness to target } \\
\text { language: }\end{array}$ & 3.53 & & 3.84 & & \\
\hline \multirow[t]{4}{*}{2.} & Pedagogical Knowledge & & & & & \\
\hline & $\begin{array}{l}\text { 2.1. Teacher educators } \\
\text { master the } \\
\text { instructional process } \\
\text { (e.g. planning, } \\
\text { teaching, and } \\
\text { assessing) }\end{array}$ & 3.21 & 3.31 & 3.46 & 3.49 & -2.723 \\
\hline & $\begin{array}{l}\text { 2.2. Teacher educators } \\
\text { possess classroom } \\
\text { management }\end{array}$ & 3.43 & & 3.56 & & \\
\hline & $\begin{array}{l}\text { 2.3. Teacher educators } \\
\text { have the ability to use } \\
\text { ICT in teaching }\end{array}$ & 3.39 & & 3.45 & & \\
\hline 3. & $\begin{array}{l}\text { Organization and } \\
\text { Communication Skills }\end{array}$ & & 3.49 & & 3.65 & -2.235 \\
\hline
\end{tabular}


3.1. Teacher educators possess the ability to organize the instruction effectively

2. Teacher educators must be able to communicate effectively with student teachers

4. Socio-Affective Skills

4.1. Teacher educators must be able to perform a good attitude in interacting with student teachers

Table 5 shows the significant statistical differences found between student teachers' and teacher educators' perceptions of the first three categories of attributes. For instance, in attribute 1 (subject matter knowledge), the t-value is -2.948 and the $\mathrm{p}=0.03$; in attribute 2 (pedagogical knowledge), the t-value is 2.723, and the $\mathrm{p}=0.006$; and in attribute 3 (organization and communication skills), the t-value is -2.235 and the $p=0.025$. Meanwhile, the analysis on the difference in attribute 4 (socio-affective skills), yield no statistical difference between student teachers' and teacher educators' perceptions since the t-value is -1.455 and the $\mathrm{p}=0.146$.

\section{Discussion}

\section{The Perceptions of the Subject Matter Knowledge}

The data findings of the present study revealed that teacher educators have higher perceptions in each mean score of items and in each mean score per indicator on the subject matter knowledge than student teachers have. It can be known from the statistical computation in each indicator of teacher educators' and student teachers' perceptions of the subject matter knowledge, as has been shown in Table 1. It means that there is a significant difference 
between student teachers' and teacher educators' perceptions of the aforementioned attribute.

Furthermore, if we look at the details of differences as has been shown in Table 1, we can figure out that differences are including mean score per item and mean score per indicator. In fact, student teachers' mean score both per item and per indicators are lower than teacher educators' means score. Although teacher educators have higher perceptions in each item and on the whole indicators, in indicator 1 (teacher educators should master four language skills) of subject matter knowledge the finding showed that teacher educators and student teachers perceived the same perceptions that mastering reading skill as the most important skill than speaking and writing skills. This finding may imply that student teachers and teacher educators attach great importance to the reading skill for EFL teacher educators.

The result of the present study supports the finding of the previous study performed by Celik, Arikan \& Carner (2013) that the most important quality of a language teacher is teaching reading, speaking, and writing. Thus, it is very important for teacher educators to master subject matter knowledge because they must be able to explain the subject or materials to be delivered in the classroom. However, the result of the present study does not support the previous finding of Yageioglu's (2016) that students perceived an effective English language teacher as someone who can teach speaking as the most necessary qualities of an effective English language teacher than teaching pronunciation, grammar, reading, and listening.

Unlike indicator 1 , in indicator 2 (teacher educators should master the language components) of subject matter knowledge, teacher educators perceived that EFL teacher educators should have good English grammar knowledge as the most important attribute, then being able to pronounce words correctly, and then have a high level of proficiency with English vocabulary. Meanwhile, student teachers perceived the most important attribute of effective EFL teacher educators as being able to pronounce English words correctly, then have good knowledge of English grammar, and then have a high level of English vocabulary proficiency.

In indicator 3 (teacher educators should have the cultural awareness to target language) of SMK, the finding shows that both student teachers and teacher 
educators perceived the similar perception that effective EFL teacher educators should have the cultural awareness of the target language. Although student teachers and teacher educators have different perceptions in each mean score in every item and indicator, they agree that teacher educators should have the cultural awareness of the target language as the first thing to have, then master the four language skills as the second, and then master the language components as the third priority to become effective EFL teacher educators.

Mastery of the SMK is important for EFL teacher educators to be able to teach effectively. Subject matter knowledge in this study includes knowledge of the English language and language components. Since English is the subject matter of foreign language teaching, language proficiency and communicative ability in English is a necessary pre-requisite for a language teacher (Richards, 1997). Apart from the teachers' capability, mastery of subject matter knowledge has a close relationship with the teacher educators' professionalism (Amin, 2013: 72).

\section{The Perceptions of the Pedagogical Knowledge}

The results of quantitative data in the present study show that teacher educators have higher perceptions in each mean score of items and in each mean score per indicator of pedagogical knowledge than student teachers have. It can be known from the statistical computation in each indicator of teacher educators' and student teachers' perceptions of pedagogical knowledge, as has been shown in Table 2. It means that there is a significant difference between student teachers' and teacher educators' perceptions of the aforementioned attribute.

Furthermore, if we look at the findings as has been shown in Table 2, we can figure out those differences of student teachers' and teacher educators' perceptions are in the mean score per item and in the mean score per indicator. In indicator 1 (teacher educators should master instructional process, e.g. planning, teaching, and assessing) of pedagogical knowledge, the finding showed that teach English tailored to students' proficiency levels, and assess students have learned were considered by teacher educators as the most important attributes of effective teacher educators. On the contrary, assess what students have learned rationally has been ranked by student teachers as 


\section{S. A. Karim}

the most important characteristic than teach English by using English as a medium of instruction, and teach English tailored to students' English proficiency levels.

Based on the finding in indicator 2 (teacher educators possess the classroom management) of pedagogical knowledge, it was revealed that both student teachers and teacher educators shared the same perception that provides interesting activities for students in learning English is the essential characteristic of effective teacher educators than teach English incorporating students' various learning styles (e.g. interactive learning style).

Furthermore, in indicator 3 (teacher educators have the ability to use ICT in teaching) of pedagogical knowledge, it was revealed that being able to use audio-visual aids when teaching is viewed as an important characteristic by both student teachers and teacher educators. In fact, nowadays, students like to make use of technology platforms in their learning activities, such as YouTube, and videos because those platforms may enhance their learning abilities and outcomes. As was found in Kulaib's study (2016: 71), using technologies may arouse student's interest in learning and drive students' attention inside the classroom.

Although student teachers and teacher educators have different perceptions in each mean score in every item and indicator of pedagogical knowledge, they shared the same perception that teacher educators should possess classroom management skills as the most important attribute of effective EFL teacher educators. Besides, teacher educators perceived that master the instructional process (e.g. planning and teaching) as the second rank, and have the ability to use ICT in teaching as the third rank to become effective teacher educators. Meanwhile, student teachers perceived have the ability to use ICT in teaching as the second rank and master the instructional process (e.g. planning and teaching) as the third rank that should be possessed by effective teacher educators.

\section{The Perceptions of the Organization and Communication Skills}

The results of quantitative data in the present study show that teacher educators have higher perceptions in each mean score of items and in each 
mean score per indicator of organization and communication skills than student teachers have. It can be known from the statistical computation in each indicator of teacher educators' and student teachers' perceptions of the organization and communication skills, as has been shown in Table 3. It means that there is a significant difference between student teachers' and teacher educators' perceptions of the aforementioned attribute.

The details of differences can be figured out from the mean scores as has been shown in Table 3 in the previous chapter. In fact, in indicator 1 (teacher educators possess the ability to organize the instruction effectively) of organization and communication skills, teacher educators highlighted to prepare appropriate materials as the most necessary attribute of effective EFL teacher educators. Moreover, provide opportunities to use English trough meaningful task and activities is the second priority, then make courses interesting to attract students' attention is the third, and then guide and train students towards independent learning is in the fourth rank, after that emphasize the most important points of the materials is in the last priority.

Similar findings were found in Kolo's (2006: 114), in which the use of suitable materials with the existing context, whether the materials required further adaptation from the teacher, and whether supplementary materials are needed. Besides, learning materials should be interesting and not monotonous, not too short and not too long. The result of the present study and Kolo's study confirms that teacher educators must select and develop appropriate learning materials in a good proportion of content and skills, deliver it in interesting ways, and to provide a variety of learning tasks or activities which allow students to get involve and engage in learning activities.

Unlike teacher educators, student teachers, in indicator 1, perceived make courses interesting to attract students' attention is the most necessary characteristic of effective EFL teacher educators. Besides, prepare appropriate materials is the second important characteristic, then provide opportunities to use English trough meaningful task and activities is the third priority, and then emphasize the most important points of the materials is in the fourth rank, and the last one priority is guide and train students towards independent learning. 
In indicator 2 (teacher educators must be able to communicate effectively with students) of organization and communication skills, teacher educators perceived have good communication skills is the most important characteristic of effective EFL teacher educators. Furthermore, maintain a good classroom atmosphere is considered as the second important characteristic while using easy language to help the student comprehend the lesson is considered as the third priority. Meanwhile, student teachers perceived the use of easy language to help the student comprehend the lesson as the most important characteristic of effective teacher educators. In addition, student teachers rated have good communication skills and maintain a good classroom atmosphere with the same degree of importance of effective EFL teacher educators.

The findings showed that although student teachers and teacher educators have different perceptions in each mean score in every item and in every indicator of organization and communication skills, they shared the same perception that teacher educators must be able to communicate effectively with student teachers as the most necessary attribute of effective EFL teacher educators, and teacher educators must be able to communicate effectively with student teachers as the second priority to become effective EFL teacher educators.

\section{The Perceptions of the Socio-Affective Skills}

Unlike the three attributes (SMK, PK, and OCS), the quantitative data finding of the present study revealed that student teachers have higher perceptions in each mean score of the item and in each mean score and each mean score per indicator on the category of the attribute in socio-affective skills than teacher educators have, as has been shown in Table 4.

Although student teachers have higher perceptions in each mean score of the item and each mean score per indicator, the result of inferential statistic analysis showed that there is no statistically significant difference between student teachers' and teacher educators' perceptions of socio-affective skills. The present finding implies that teacher educators at present are aware of the importance of personal qualities of EFL teacher educators.

In fact, in indicator 1 (teacher educators must be able to perform a good attitude in interacting with student teachers) of socio-affective skills, both 
student teachers and teacher educators shared the same perception that being friendly to students is the most important attribute of effective EFL teacher educators. It is in line with Berline's study (2000), Mulock (2003) that developing a good relationship with students leads to teachers' effectiveness and good quality of teachers.

A similar finding was found in Yageioglu's study (2016: 87) that being friendly is found to be a necessary quality of an effective English language teacher. Concerning the present finding, several studies showed similar results that show the importance of being friendly, for instance; Arikan, Taser \& Suzer, 2008; Shishavan, \& Sadegi, 2009; and Celik, Arkan \& Caner, 2013. In addition to this characteristic, both student teachers and teacher educators shared the same perception that has a great sense of humour is considered as the second rank to be possessed by EFL teacher educators.

A similar finding can be observed in Puspita's study (2013: 73) that students intend to have teachers who always smile and fun to be with them. When a teacher has the skill to approach students in difficult situations in the classroom with the use of humour, it can create an interesting atmosphere in the classroom. This finding also matches with McDermott and Rothenberg' statement (2000) that students enjoy teachers with a good sense of humor and fun learning.

Meanwhile, in indicator 2 (teacher educators must be able to fully motivate, encourage, and reduce students' anxiety) of socio-affective skills, both student teachers and teacher educators also have the same perception that has an interest in students (e.g. remembering students' names), and students' English learning as the most important attributes of effective EFL teacher educators. Similar findings were obtained in the study conducted by Park and Lee (2006). They stated that professional qualities and classroom behaviours that should be possessed by EFL teachers include reduce students' anxiety and know students' names.

The finding of the present study revealed that being friendly to students, possesses a great sense of humour, and has an interest in students and their learning are considered important by both student teachers and teacher educators. It is evidence that socio-affective skills are highly rated as an 


\section{S. A. Karim}

important characteristic of effective EFL teachers educators. The finding of the present study indicates that teacher educators nowadays, tend to have a warm and friendly relationship with their students, and always build a good rapport with student teachers to gain the effectiveness of the learning and teaching process.

\section{The Perceptions of the Whole Categories of Attributes}

Based on the findings of the quantitative data analysis from student teachers' and teacher educators' questionnaires on the whole category of attributes they have different perceptions of effective EFL teacher educators. The result of statistic analysis revealed that teacher educators have a higher mean score on the whole category of attributes than the student teachers have, as has been shown in Table 5 .

Moreover, as stated previously, there is a significant statistical difference between student teachers' and teacher educators' perceptions of the three categories of attributes, namely SMK, PK, and OCS. However, as has been shown by Table 5 , there is no significant statistical difference between student teachers' and teacher educators' perceptions of socio-affective skills despite the fact that student teachers' mean score in each item and each indicator is higher than the teacher educators' mean score.

A similar finding can be found in the related study conducted by Puspita (2013: 66) that there were no significant differences between the two groups on interpersonal skill (e.g. help students in learning, and praise students' ability and opinion) which is closely related to the term SAS in the present study. Thus, they both perceived the attributes as the necessary attributes of becoming effective EFL teacher educators.

\section{CONCLUSION}

The student teachers and teacher educators have different perceptions of how they perceived effective EFL teacher educators. They are different in the three categories of attributes namely SMK, PK, and OCS. However, no significant statistical difference was found between student teachers' and teacher educators' perceptions of socio-affective skills. The differences might be caused 
by several factors, such as students' learning needs, expectations, and learning orientation. Besides, they have a different point of views about the role of teacher educators inside and outside of the classroom, teacher educators' teaching performances in the classroom, as well as their educational background and empirical experiences among them.

\section{Suggestions}

It necessary for EFL teacher educators to pay attention not only to the aspects of mastery of the subject (what to teach) and pedagogical knowledge (how to teach), but also to observe socio-affective skills, including personal qualities, and organization and communication skills. Meanwhile, to student teachers, it is suggested that they observe and comprehend the attributes of effective teachers from the teacher educators' point of view.

To the curriculum developers, it is strongly suggested and recommended that will take into account the results of the study by considering the category of attributes of effective EFL teacher be integrated into a certain course like microteaching, peer teaching, instructional design, teaching and learning strategies, and syllabus design. Moreover, the study program coordinators at the English Education Program may also conduct teacher educators' evaluations from the perspectives of student teachers by inserting those attributes as one of the assessment criteria.

Besides, those attributes may also be applied to one of the assessment criteria in the student teachers' field teaching practice final score form. Thus, a great combination of performance and competence which is highlighted in the four categories of attributes of effective teachers may be established for student teachers before graduating from the teacher education program.

Finally, to the prospective researchers to conduct, for instance, an in-depth study into the differences between male and female student teachers, between high and low proficiency students about effective teacher educators. Another investigation might be conducted qualitatively to find out effective language teachers from the perspectives of student teachers whose family from the teaching profession and non-teacher professional background. Future researchers can compare and contrast their perceptions to get comprehensive information about what makes a teacher educator effective. 


\section{Pedagogical Implications}

The implication of the present study that teacher educators will understand how to approach the students in a great way, what teaching methods suit them, how to organize the classroom (classroom management), and provide types of activities during the teaching and learning process. Moreover, the present findings may serve as starting points to teacher education providers, curriculum developers, student teachers, and the related authorities to take any necessary actions and implement prominent strategies in the initial teacher education program in Indonesia, especially in the university context.

\section{Acknowledgements}

The author would like to thank the participants both teacher educators and student teachers for their availability and willingness to involve in the data gathering process.[rgt]

\section{REFERENCES}

Afshar, H.S., \& Doosti, M. (2014). Exploring the Characteristics of Effective

Iranian EFL Teachers from Students' and Teachers' Perspectives. Iranian Journal of Applied Language Studies, 6 (1), 205-230.

Alimorad, Z., \& Tajgozari, M. (2016). A Comparison of Iranian High School Teachers' and Students' Perceptions of Effective English Teachers. Sage Open, 6 (4), 1-10. https://doi.org/10.1177/2158244016679212.

Al-Issa, A.S.M. (2017). Qualities of the Professional English Language Teacher Educator; Implications for Achieving Quality and Accountability. Journal Cogent Education, 4(1), 1-17.

Amin, M. (2013). What makes Teachers of EFL Professional or Unprofessional? Unpublished Dissertation. Malang: PPS UM.

Anugerahwati, M. (2009). Professional Competence for Teachers of English in Indonesia: A Profile of an Exemplary Teacher. Unpublished Dissertation. Malang: PPS UM.

Arikan, A., Taser, D., \& Suzer, H.S.S. (2008). The Effective English Language Teacher from the Perspectives of Turkish Preparatory School Students. Education and Science, 33 (150), 42-51. 
Bell, T, R. (2005). Behaviours and Attitudes of Effective Foreign Language Teachers: Results of a Questionnaire Study. Foreign Language Annals, 38 (2), 259-270. http://dx.doi.org/10.1111/j.1944-9720.2005.tb02490.x.

Celik, S, Arikan, A., \& Caner, M. (2013). In the eyes of Turkish EFL learners: What makes an Effective Foreign Language Teacher? Porta Linguarum, 20, 287297.

Chen, J. (2012). Favorable and Unfavorable Characteristics of EFL Teachers Perceived by University Students of Thailand. International Journal of English Linguistics, 2(1), 213-219. http://dx.doi.org/10.5539/ijel.v2n1p213.

Cheung, H. Y. (2006). The Measurement of Teacher Efficacy: Hong Kong Primary In-service Teachers. Journal of Education for Teaching, 32 (4), 435-451.

Clark, J. C., \& Walsh, J. (2002). Elements of a Model of Effective Teachers. AARE 2002 Conference Papers. http://www.aare.edu.au/02pap/wal02220.htm. etrieved on October 17, 2018.

Dincer, A.D., Goksu, A., Takkac, A., \&Yazict, M. (2013). Common Characteristics of an Effective English Language Teacher. TheInternational Journal of Education Researchers, 4(3), 1-8.

Goodwin, A. L., \& Kosnik, C. (2013). Quality Teacher Educators = quality Teachers? Conceptualizing Essential Domains of Knowledge for those who Teach Teachers'. Teacher Development, 17 (3), 334-346.

Khojastehmehr, R., \&Takrimi, A. (2009). Characteristics of Effective Teachers: Perceptions of the English Teachers. Journal of Education \& Psychology, 3 (3), 53-66.

Kolo, C. (2006). A Potrait of a Good EFL Teacher: A Study on Teachers'Perspectives. Unpublished Dissertation. Malang: PPS UM.

Kourieos, S., \& Evripidou, D. (2013). Students' Perceptions of Effective EFL Teachers in University Settings in Cyprus. English Language Teaching, 6(11), 1-16. http://dx.doi.org/10.5539/elt.v6n11p1.

Kulaib, M. (2006). Perception on Ideal EFL Teachers of Undergraduate English Students Across Achievement and Socio-Economic Background. Unpublished Thesis. Malang: PPS UM.

McDermott, P., \& Rothenberg, J. (2000). The Characteristics of Effective Teachers in high poverty Schools: Triangulation of our data. Paper presented at the annual meeting of the American Educational Research Association, New Orleans, (ERIC Document Reproduction Service No. ED442887. Educational Research Association, New Orleans. 
Mudra, H. (2018). A Study on teh Attributes of Effective English Lecturers as perceived d by EFL Learners: The Case of Indonesia. Journal of Language and Education, 4(2), 59-67.

Mullock, B. (2003). What makes a good Teacher? The Perceptions of Postgraduate TESOL Students. Prospect, 18 (3), 6-24.

Puspita, D, I. (2013). Students' and Teachers' Perceptions about Characteristics of Good English Teachers of Seniot High Schools in Madiun. Unpublished Thesis. Malang: PPS UM.

Richards, J, C. (1997). Preparing Language Teachers for tomorrow's Language Classroom. In Jacobs, G. M.(Ed). (1997), Language Classroom of of tomorrow: Issues and responses (pp. 16-35). Singapore: SEAMEO Regional Language Centre

Said, M. (2017). Effective Behavior of EFL Teachers as Perceived by Undergraduate Students in Indonesia. English Language Teaching, 10(7), 5062. https://doi.org/10.5539/elt.v10n10p50

Shishavan, H. B., \& Sadeghi, K. (2009). Characteristics of Effective English Language Teacher as Perceived by Iranian Teachers and Learners of English. English Language Teaching, 2 (4), 130-142.

Thompson, S., Greer, J., Greer, G. (2004). Highly Qualified for Successful Teaching: Characteristics every Teacher should Possess. Essays in Education, 10 (2), 57.

Wichadee, S. (2010). Characteristics of Effective English Language Teachers: The Perspectives of Bangkok University Students. http://www.bu.ac.th/ knowledgecenter/epaper/jan_june2010/pdf/Page_01.pdf.

Yageioglu, S. (2016). Students' and Teachers' Perceptions of an Effective English Language Teachers. Unpublished Master Thesis. North Cyprus: Eastern Mediteranean University.

Yuan, R., \& Hu, Y. (2018). Teachers' views on the Qualities of Effective EFL Teacher Educators. ELT Journal, 72 (2), 141-150.

Zamani, R., \& Ahangari, S. (2016). Characteristics of an Effective English Language Teacher (EELT) as Perceived by Learners of English. International Journal of Foreign Language Teaching \& Research, 4, (14), 70-88. 